\title{
Effect of Processing on the Nutritive Value of Clarias gariepinus from Isinla Fish Pond, Ado Ekiti, Nigeria
}

\author{
Adewumi Adejoke Abeni ${ }^{1,}$,, Ogunlade Ibiyinka ${ }^{2}$, Coker Folakemi Funmilayo ${ }^{1}$ \\ ${ }^{1}$ Dept. of Zoology, Ekiti State University, Ado Ekiti, Nigeria \\ ${ }^{2}$ Dept. of Chemistry, Ekiti State University, Ado Ekiti, Nigeria
}

Email address:

zoewumi@gmail.com (A. A. Abeni)

\section{To cite this article:}

Adewumi Adejoke Abeni, Ogunlade Ibiyinka, Coker Folakemi Funmilayo. Effect of Processing on the Nutritive Value of Clarias gariepinus from Isinla Fish Pond, Ado Ekiti, Nigeria. American Journal of BioScience. Vol. 3, No. 6, 2015, pp. 262-266.

doi: 10.11648/j.ajbio.20150306.19

\begin{abstract}
As some consumers in Nigeria showed preference for some form of method of processing/preservation of $C$. gariepinus, this study investigated the proximate and mineral composition of the fillets of a pond raised Clarias gariepinus, using the common methods of smoking and oven drying. The biochemical assay of the moisture, ash, crude protein, fibre, lipid and the elements, Fe, $\mathrm{K}$ and $\mathrm{P}$ of the fillets were done in the laboratory. The protein and fat contents of the oven dried $\left(43.7 \% \pm 1.32^{\mathrm{a}} ; 22.2 \pm 0.35\right)$ and smoked $(32.3 \pm 1.07 ; 13.5 \pm 0.17)$ samples were significantly higher $(\mathrm{P}>0.05)$ than those of the wet samples $(16.2 \pm 1.00 ; 8.02 \pm 0.57)$. The general trend observed is increase in protein, lipid, fibre and carbohydrate contents of the fish fillets, as they were subjected to various drying methods, in the order of wet $<$ smoked $<$ oven-dried and the reverse applicable to the moisture contents wet $>$ smoked $>$ oven-dried). The ash and the crude fibre contents of the fish fillets were low. The fillets were rich in minerals. The values of phosphorus, iron and potassium obtained in the oven dried and smoked samples were significantly higher $(\mathrm{p}>0.05)$ than those obtained for the fresh fish and the values of phosphorus and potassium obtained in the fish samples were higher than the iron content. The catfish in this pond, irrespective of the processing method, belonged to high protein (16.2-43.7\%) and high fat (8.02-22.2\%) fish group This study has shown that oven-drying and smoking concentrated the micro and macronutrients and provide a relative nutritional stability for the catfish meat and also enable the fish provide higher percentage of protein, fats and minerals, which are essential nutrients that could satisfactorily supplement cereals, the staple foods of the Nigerian people.
\end{abstract}

Keywords: Lipid, Protein, Smoking, Fresh, Oven-Dried, Fillets, Minerals

\section{Introduction}

Proximate analysis is used to estimate the relative amounts of protein, lipid, water, ash and carbohydrate in an organism. Protein, lipid and carbohydrate contribute to the total energy content of an organism while water and ash only contribute mass. Energy content is frequently used as expression of a fish's condition or health status. However, the relative contribution of lipid, protein and carbohydrate to a fish's total energy vary in response to specific life history demands.

Fish contains an important component that is suited for human diet and it also provides the much needed minerals and vitamins that are not available in cereal based diets. Fish is a good source of animal protein and it provides about 30$80 \%$ of the protein intake of the coastal people of West Africa, including Nigeria. Furthermore, [1] also pointed out that fish is rich in protein with amino acid composition which is essential for the maintenance of a healthy body, and compares very well with egg, milk and meat in the nutritional value of its protein. Fish quality is an important attribute, which is affected by many factors such as food availability in the ecosystem, fertilization [2], feed composition [3], feeding rates, the water quality of the aquatic environment and of course, the method of processing and preservation.

Fish, as soon as it is caught is susceptible to damage. There is therefore need for preservation of fish which generally slows down spoilage. A number of processing techniques, such as, smoking, freezing, chilling, salting, drying and fermentation are employed by fish processors in Nigeria [4]. However, smoking is the affordable and most widely used method for fish preservation in Nigeria, Ghana and other West African countries [5, 6]. [7] reported that up 
to $70 \%$ of the total fish catch in several communities in the third world are smoked. The smoking of fish has the objectives of preservation basically due to dehydration, high temperature of smoking $\left(50-180^{\circ} \mathrm{C}\right)$, the preservative effects of smoke components (phenols, aldehydes, ketones, organic acids etc.) and for purpose of product development due to changes in organoleptic, nutritional, chemical and physical properties during processing [8].

The relationship between pathogens and food intake has been elucidated by investigation into proximate composition and fatty acid content of food items [9]. The fatty acid content of a diet modulates the fatty acid profile of immune cells. This may be an effective way to regulate the functionality of normal cells through nutrition. [3] indicated that diets, in which unsaturated fatty acids replace the saturated ones, are associated with low incidence of coronary diseases, in order to reduce the risk of cardiovascular diseases. Emphasis has now been placed on the increased consumption of fish and fish products, which are rich in polyunsaturated fatty acids (PUFA) of the omega (w)-3 family, and poor in polyunsaturated fatty acids of w-6 family [11].

The most common application of the measurement of food composition, in industry, is in quality controls. It is seldom necessary to analyze a product completely; often the measurement of only a single component is required. Nutritionist and dieticians also need to know the proximate composition of all foods in order to estimate the intake of the principal nutrients in the human diets and to calculate energy values of different foods. Extensive compilations of the composition of foods are available at Torry Research Station [12]. This information was derived from proximate analysis made over a long period. These tables also include details of individual substances such as minerals and vitamins.

Regular updating of the tables is required because of the changes in the nature and source of raw materials and in manufacturing processes.

There is, however, dearth of accurate basic chemical composition data for fish species particularly from African and Asian countries [6].

The present knowledge of the biochemical composition of fish species from Nigerian waters is very limited. The Clarid, C. gariepinus is generally considered to be one of the most important tropical catfish species for agriculture. It is easily cultured in Nigeria and is of great economic interest. This study is, therefore, designed to investigate a proximate assay of the fillets of $C$. gariepinus raised in Isinla pond, compared to the wild species harvested from Ado Ekiti and Ero reservoirs, in Ekiti state, Nigeria.

\section{Main Text}

\section{Materials and Methods Collection of Samples}

The C. gariepinus was bought from Isinla fish pond, AdoEkiti, Ekiti State, Nigeria. The samples collected were virtually of the same size (av. Wt $340 \mathrm{~g} \pm 15$ ) as variability in size stands to affect the proximate composition. All the samples were collected fresh and refrigerated at a temperature of $20^{\circ} \mathrm{C}$ prior to use. Three samples were oven dried in an electric oven, at between $60-70^{\circ} \mathrm{C}$ until the sample had constant weight and another set of three samples were smoke-dried using the local kiln method. Three wet samples were analyzed.

\section{Biochemical Analysis}

The samples were taken to Afe Babalola University, Ado Ekiti (ABUAD) Cenral Laboratory, for analysis. The fillet of each dry sample was ground with mortar and pestle. From each composite sample; $2 \mathrm{~g}$ was taken as analytical sample for protein, fat, ash, fibre, carbohydrate and moisture content, according to the method of analysis described by the Association of Official Analytical Chemist [14]. Moisture content of the fish was determined by drying samples to a constant weight at $100-102^{\circ} \mathrm{C}$ for 16 hours in a draft air oven. The loss in weight was recorded as moisture. Crude ash was determined by incineration of the fish samples in a muffle furnace at $500-600^{\circ} \mathrm{C}$. The water and other volatile constituents evolved as vapours. The organic constituents in the fish were also burnt to carbon dioxide and water. The inorganic residue constitutes the ash in the food products.

The crude protein of the fish sample was determined by the Kjeldahl nitrogen method. This gives the amount of all the reduced nitrogen in the food in the form of amines, ammonium compounds, urea and amino acid. The protein value was obtained by multiplying the total nitrogen by a factor, 6.25 for fish products. The crude fat was determined by the Soxlet method and was based on the sparingly solubility of lipids in water and their considerable solubility in non-polar organic solvents. Crude fibre, which is indicative of the indigestible matter or roughage in the fish, was determined by the trichloroacetic acid method.

The raw fish was defatted and the protein and carbohydrate content hydrolyzed using a mixture of trioxonitrate (v) acid, glacial acetic acid and trichloroacetic acid.

\section{Results and Discussion}

Table 1 indicates the concentration and percentage of proximate (protein, ash, carbohydrate, moisture, fibre and fat) composition of fresh, smoked and oven dry $C$. gariepinus. The result shows that the highest moisture content $(70.6 \pm 0.93)$ was recorded in fresh $C$. gariepinus obtained from Isinla fish pond while the lowest $(10.9 \pm 0.61)$ was found in the oven-dried $C$. gariepinus. There was significant $(\mathrm{P}>0.05)$ reduction in moisture content when the fish was oven dried and smoked. The moisture content was therefore in the order; fresh $>$ smoked $>$ oven dried.

Processing, by heating method, reduces moisture drastically. [15] reported that high moisture content is a disadvantage in that it increases the fishes susceptibility to microbial spoilage, oxidative degradation of polyunsaturated fatty acids and consequently decreases in the quality of the fishes for longer preservation time. [16] (9) also reported that about three quarter of the body weight of catfish consists of 
water. According to [17], the water content in fish affects the microbiological and chemical stability, physical properties, processing, storage and distribution of fish. A safe moisture level of 6 to $8 \%$ in dried fish has been recommended in order to prevent spoilage due to microbe and pest proliferation [18]. In this study, more water contents were rapidly removed in the fish exposed to oven-drying than smoked-drying.

The oven-dried sample has the highest protein value of $43.7 \pm 1.32$, which was significantly different $(\mathrm{P}>0.05)$ from the value for the smoked sample $(32.3 \pm 1.07)$ and fresh sample $(16.2 \pm 1.00)$ respectively. The significant increase in protein levels in oven-dried and smoked-dried catfish when compared with the wet fish samples suggests that protein nitrogen was not lost during drying. This is in agreement with the findings of [19] and [20]. The authors noted that increase in protein contents maybe due to product dehydration which concentrated the proteins during the heat treatment, thus increasing the nutritional value of the catfish. Similar results for chemical composition of oven dry fish have also been reported by [21]. These workers opined that oven drying resulted in concentration of nutrients like crude protein. Also, the relatively high to moderate percentage crude protein may be attributed to the fact that fishes are good source of pure protein. [22] reported that oven-dried fish had higher protein than the fresh fish because increase of protein may be due to the dehydration of water molecule present between the proteins thereby causing aggregation of protein and thus resulting in the increase in protein content of oven-dried fishes. The samples studied here, irrespective of the processing method, belonged to high protein (15 to 20\%) fish group, according to the classification of [16].

The ash content of the fillets of the three samples were significantly different $(\mathrm{P}>0.05)$ from one another. The ash content of the smoked sample (3.22 \pm 0.42$)$ and oven dried sample (4.65 \pm 0.14$)$ were higher than that of the wet sample $(1.19 \pm 0.16)$. The observation in this work is in agreement with [23] who reported that the increase in ash content when fish are smoked and oven dried is due to loss of humidity. [24] also reported that the inorganic content remains as ash, after the organic matter is removed by incineration. [25] reported that the total ash value is an indicator of the total mineral element contents in fish.

There was an increase in the fat contents of the two processed samples. The fat contents of the oven dried $(22.2 \pm 0.35)$ and smoked (13.5 \pm 0.17$)$ samples were significantly higher $(\mathrm{P}>0.05)$ than that of the wet sample $(8.02 \pm 0.57)$. It was apparent that $C$. gariepinus could be regarded as a fatty fish species. [26] reported that fish with moderate fat contain low cholesterol and are good sources of omega-3 fatty acids which protect against heart rhythm disorders and has benefits for blood clothing and blood vessel function. Based on the 5\% fat composition criteria for discriminating lean fish from fatty species, it was apparent that $C$. gariepinus could be regarded as a fatty fish species. [27] however revealed that lipid contents of fish fluctuate considerably with age, feed and sexual cycle of fish.

The highest amounts of carbohydrate contents $(3.74 \pm 0.85$;
$3.02 \pm 0.13$ ) were present in the oven-dried and smoked-dried samples respectively, while the lowest amount $(2.92 \pm 0.71)$ was found in the wet sample. The carbohydrate contents of the differently processed fish fillets were not significantly different $(\mathrm{P}<0.05)$ from each other. The carbohydrate content in fish is generally very low compared with protein or fat content [28]. The main function of carbohydrates is to provide energy to the body so as to perform muscular contractions and numerous physiological functions. Low carbohydrate diets have been reported to lower blood pressure by causing weight loss and improving the insulin sensitivity in diabetics [29].

Table 1. Proximate composition (\%) of the fish samples $C$. gariepinus from Isinla fish pond.

\begin{tabular}{llll}
\hline Components & Wet & Oven dried & Oven dried \\
\hline Moisture & $70.6 \pm 0.93^{\mathrm{a}}$ & $26.4 \pm 1.15^{\mathrm{b}}$ & $10.9 \pm 0.61^{\mathrm{c}}$ \\
Crude protein & $16.2 \pm 1.00^{\mathrm{c}}$ & $32.3 \pm 1.07^{\mathrm{b}}$ & $43.7 \pm 1.32^{\mathrm{a}}$ \\
Crude fibre & $0.62 \pm 0.76^{\mathrm{b}}$ & $1.65 \pm 0.71^{\mathrm{ab}}$ & $2.14 \pm 0.13^{\mathrm{a}}$ \\
Fat & $8.02 \pm 0.57^{\mathrm{c}}$ & $13.5 \pm 0.17^{\mathrm{b}}$ & $22.2 \pm 0.35^{\mathrm{a}}$ \\
Ash & $1.19 \pm 0.16^{\mathrm{c}}$ & $3.22 \pm 0.42^{\mathrm{b}}$ & $4.65 \pm 0.14^{\mathrm{a}}$ \\
Carbohydrate & $2.92 \pm 0.71^{\mathrm{b}}$ & $3.02 \pm 0.13^{\mathrm{b}}$ & $3.74 \pm 0.85^{\mathrm{a}}$ \\
\hline
\end{tabular}

Means with the same superscripts in the same row are not significantly different $(\mathrm{p}<0.05)$

The crude fibre values recorded for the wet sample, smoked and oven dried samples $(0.62 \pm 0.76 ; 1.65 \pm 0.71$ and $2.14 \pm 0.13)$, respectively, were low in all the fish samples and significantly different $(\mathrm{P}>0.05)$ from one another. [30] and [31] reported that crude fibre content in fish fillets is meager or absent.

The general trend observed in this work is increase in protein, lipid, fibre and carbohydrate content of fish fillets as they were subjected to various drying method, in the order of wet $<$ smoked $<$ oven-dried and the reverse was applicable to the moisture content (i.e oven-dried $<$ smoked $<$ fresh). The ash and the crude fibre in the fish fillets were significantly low. This trend has also been reported for Parachanna obscrura (30), Heterobranchus bidorsalis (32), croaker fish, Pseudotolithus elongates, (33) C. gariepinus [34, 35] and salmonid trout, Salmo truta [23], when oven or smoke dried.

However, according to the report of [36], some studies have observed reductions in the quality of protein as a result of smoking and probably oven-drying. The loss in available lysine may vary from $6-33 \%$ at $25^{\circ} \mathrm{C}$ to $53-56 \%$ at $40^{\circ} \mathrm{C}$ during heating and a $25 \%$ loss of available lysine on the surface and a loss of $12 \%$ at the center of hot smoked fish (37. (38 observed that lysine reduction was directly proportional to the temperature and duration of smoking. The positive effect of heat intensity on the shelf life of smoked products has been reported by several researchers. $\mathrm{CO} 2$ is reported to have an important effect on microbial growth, exerting a selective inhibitory action [39]. [40] and [41] that the components in the wood/charcoal via pyrolysis are broken down in the process of burning to form smoke, thus it gives the fish a unique aroma and improves its taste and colour. This is due to the presence of a range of phenolic 
compounds, nitrites and formaldehyde present in the smoke.

The results of the mineral component of the fillets are represented in Table 2. The values of phosphorus, iron and potassium obtained in the oven dried and smoked samples were significantly higher $(p>0.05)$ than those obtained for the wet fish. The values of phosphorus and potassium obtained in the fish samples were higher than the iron content. This is in agreement with some previous workers [42, 36] who observed high values of phosphorous and low iron contents in the some tropical smoked freshwater studied. Freshwater fish meat is a particularly valuable source of calcium and phosphorus as well as iron, copper and selenium [46, 44] reported similar findings and observed that the dominance of mineral elements in a fish depends on the water body where the fish lives.

Table 2. Trace mineral composition $(\mu \mathrm{g} / \mathrm{ml})$ of the fillets of the C. gariepius.

\begin{tabular}{llll}
\hline & Processing & Method & \\
\hline & Wet & Smoked & Oven dried \\
\hline Phosphorus & $1.64 \pm 0.01^{\mathrm{c}}$ & $5.78 \pm 0.03^{\mathrm{a}}$ & $6.01 \pm 0.12^{\mathrm{a}}$ \\
Iron & $0.15 \pm 0.11^{\mathrm{c}}$ & $0.61 \pm 0.02^{\mathrm{b}}$ & $1.03 \pm 0.01^{\mathrm{a}}$ \\
Potassium & $0.89 \pm 0.04^{\mathrm{c}}$ & $1.31 \pm 0.01^{\mathrm{b}}$ & $2.01 \pm 0.12^{\mathrm{a}}$ \\
\hline
\end{tabular}

Means with the same superscripts in the same row are not significantly different $(\mathrm{p}<0.05)$

This study shows that $C$. gariepinus from ponds is a valuable source of essential nutrients for human consumption. It contains huge amount of proteins, fats and minerals that are essential for both infants and adults in the appropriate quantity.

\section{Conclusion}

The results in this study showed that there were significant influences of the processing method on the catfish fillet samples in relation to the moisture, ash, crude fibre, protein, fat and carbohydrate contents. Oven-dried and smoked could provide a relative nutritional stability for the catfish meat and also enable the fish provide higher percentage of protein, fats and minerals, which are essential nutrients that could satisfactorily supplement cereals, which are the staple foods of the Nigerian people. More intake of fish should be encouraged due to its high nutritional efficiency.

\section{Acknowledgements}

Many thanks for all the staff of the Department of Zoology laboratory, EKSU, who helped with the handling and identification of this fish and the staff of ABUAD Central Laboratory, for the biochemical analysis.

\section{References}

[1] J. M. Olomu, Monogastric Animal Nutrition. Jachem Publications, Benin City Nigeria 1995, p165-200.

[2] M. Hassan, Polyculture of major carps under broiler manure fertilization of ponds. Poult., 1996, 2(2): 65-71.
[3] M. Javed; A. N. Sheri, S. Hayat and M. Hassan; Organoleptic evaluation of fish reared under organic and inorganic fertilizers and feed supplementation of ponds. Pak. J. Agri. Sci., 1995, 32 (2-3): 1-4.

[4] F. O. Akinwumi; Effects of smoking and freezing on the nutritive value of African mud catfish, Clarias gariepinus Burchell, 1822. J. of Agric. Sci., 2014, 6, (11): 143-149.

[5] O. T. Adeyemi, O. O. Osilesi, F. Onajobi, O. Adebawo and A. J. Afolayan (2013). Stability study of smoked fish, horse mackerel (Trachurus trachurus) by different methods and storage at room temperature. Afr. J. of Biochem. Res., 7(6): 98-106.

[6] H. D. Nyarko, E. A. Obodai, L. K. Boamponsem, S. S. Coomson and Y. Aniwe (2011). Microbial profile of smoked sardine (Sardilella aurita) at smoking sites and market centres of Tema, Ghana-1. Arch. of Appl. Sci. Res., 3(3), 443-453.

[7] A. R. Ward, Fish smoking in the tropics. A review. Trop. Sci., 1995, 35: 103-112.

[8] L. A. Luzai, G. R. Sampaio, C. M. N. Castellucci and E. A. F. S. Torres, The influence ofseason on the lipid profiles of five commercially important species of Brazillian fish. Food Chem..2003, 83: 93-97.

[9] J. A. G. Fuentes, Que alimentosconvemaocoracao? Hig. Aliment. 1998, 12(53): 7-11.

[10] J. R. Sargent, Origins and functions of egg lipid. In: Broodstock Management and Eggand Larval quality, N. R. Bromage and R. J. Roberts (eds). Blackwell, London, 1996, p 353-372.

[11] J. E. Halver, The history of fish nutrition. Proceedings of the International Workshop on Fish Nutrition and Growth. Y. Cui and X. Xie (eds), Wuhan, China, 1999, p 14-21.

[12] H. C. Schonfeldt, Food composition program of AFRO FOODS. J. of Food Comp. and Anal., 2002, 15: 473-479.

[13] AOAC (Association of Official Analytical Chemists), Official methods of analysis, $17^{\text {th }}$ Edition. (Ed. S. Williams), Arlington, V.A. 2006, 1125p.

[14] O. O. Omolara and O. D. Omotayo, Preliminary studies on the effect of processing methods on the quality of three commonly consumed marine fishes in Nigeria. Biochem. J., 2008, 21: 1-7.

[15] F. Olayemi, E. Adedayo, E. Bamisaye and E. Awagu, The nutritional quality ofthree varieties of Zobo (Hibiscus sabdariffa) subjected to the same preparation condition. Am. J. Food. Tech. 2011, 6(8): 705-708.

[16] V. Silva and G. Santos, Determination of moisture content and water activity in algae and fish by thermo analytical techniques. Quimica Nova, 2008, 31(4):901-905.

[17] B. Effiong, and I. Mohammed, Effect of seasonal variation on the nutrient composition in selected fish species in Lake Kainji, Nigeria. Nat. and Sci., 2008, 6(2): 1-5.

[18] K. Judprasong and E. Kettwan, Proximate composition of raw and cooked Thai freshwater and marine fish. J. Food Comp. Anal., 1999, 12: 9-16.

[19] W. Tao and M. Linchum, Influence of hot air drying and microwave drying on nutritional and odorous properties of grass carp (Ctenopharyngodon idellus) fillets. Food Chem., 2008, 110(3): 647-653. 
[20] P. E. Doe and J.Olley, Drying and dried fish products. Proceedings of the workshop on the production and storage of dried fish, Nov. 2-5, 1982, FAO. 1983, p56-62.

[21] A. S. Niwaye and K. Rathnakumar, Fish processing technology and product development: Impact of Curing $\left(1^{\text {st }}\right.$ ed). Alden Publications, New York, USA. 2008, p5: 142.

[22] O. E. Salan, A. G. Juliana and O. Marilia, Use of smoking to add value to SalmonId trout. Braz. Arc. of Biol. and Tech., 2006, 49(1), 57-62.

[23] I. J. Clucas and A. R. Ward, Harvest fisheries development; A guide to handling, preservation, processing and quality. Natural Resources Institute, UK. 1996, 5: 428.

[24] E. Owaga, C. Onyango and C. Njoroge, Effects of selected washing and drying temperatures on bacterial quality and safety of dagaa (Rastrineobola argentea). J. Tropic. Microbiol. Biotech., 2009, 4(1): E. Deckere, Possible beneficial effect of fish and fish n-3 polyunsaturated fatty acids in breast and colorectal cancer. European J. Cancer Prev.1999, 8: 213-221.

[25] A. Turkkan, S. Cakli, and B. Kilinc, Effects of cooking methods on the proximate composition and fatty acid composition of sea bass, Dicentrarchus labrax (Linnaeus 1758). Food and Bioproducts Proc., 2008, 86: 163-165.

[26] A. I. L. Payne, Confronting uncertainty in the evaluation and implementation of fisheries management systems. ICES J. Mar. Sci., 1999, 44:56-60.

[27] S. Holden, K. Hudson, J. Tilman and D. Wolf, Genomic plasticity of the causative agent of melioidosis, burkholderia, and pseudomallei. Proceedings of the National Academy of Science of the United States of America, 2003, 10(39): 1424014245 .

[28] A. Daniel and A. Ogar, Proximate analysis of snakehead fish, Parachanna obscura, (Gunther 1861) of the Cross River. Nig. J. of Fish. and Aqua. Sci. 2013, 8: 295-298.

[29] A. A. Adewumi, H. A. Adewole and V. F. Olaleye, Proximate and elemental composition of the fillets of some fish species in Osinmo Reservoir, Nigeria. Agric. and Biol. J. of North America (ABJNA). 2014, 5(3): 109-117.

[30] O. J. Abolagba, and S. J. Osifo, The effect of smoking on the chemical composition andkeeping qualities of catfish (Heterobranchus bidorsalis), using two energy sources. J. Agric. Forestry and Fish., 2004, 51:27-30.

[31] A. O. Abraham-Olukayode and C. E. Oramidike, Biochemical and bacteriological assessment of fresh and processed croaker fish, (Pseudotolithus elongates) J. Sci. Tech.2011, 10: 100-105.

[32] O. O. Fapohunda and M. Ogunkoya, Effect of smoke-drying on the proximate composition of Tilapia zillii, Parachanna obscura and Clarias gariepinus obtained from Akure, Ondo State, Nigeria. Anim. Res. Intern. 2006, 3(2), 478-480.

[33] C. Ogbonnaya, and I. M. Shaba, Effects of drying methods on proximate composition of catfish (Clarias gariepinus). World J. Agric. Sci. 2009, 5(1): 114-116.

[34] F. O. Akinwumi, Effects of smoking and freezing on the nutritive value of African mudcatfish, Clarias gariepinus (Burchell 1822). J. of Agric. Sci. 2014, 6(11): 143-149

[35] M. N. Clifford, S. L. Tang, and A. A. Eyo, The development of analytical methods for investigating chemical changes during fish smoking. In: Advances in Fish Science and Technology. Fishing News Books Limited, Farnham. 1980, p 286-290.

[36] G. R. Akande, O. H. Oladosu and J. G. Tobor, A Comparative technical and economic appraisal of fish smoking: Two traditional ovens and a new Improved Magbon-Alade oven. FAO Fisheries Report 574, 1998, p 70-75.

[37] H. H. Huss, Storage life of prepacked wet fish at $0^{\circ} \mathrm{C}$ I Plaice and haddock at $0^{\circ} \mathrm{C}$. J. of Food Tech.1992, 7:13-19.

[38] J. Olley, P. E. Doe and E S. Heruwati, The influence of drying and smoking the nutritional properties of fish. An Introduction: Overview in fish smoking and drying. Elsevier, London. 1988, p56.

[39] IMPPFA, Ingredients in meat product. Archives imppfa. rar. Filmed at the Institute of Food Technology Conference. http://www.general-files.com/files-i/ingredients-in-meatproducts Retrieved $20^{\text {th }}$ Oct. 2014.

[40] B. N. Effiong, and J. O. Fakunle, Proximate and mineral content of traditional smoked fish species from Lake Kainji, Nigeria. Bull. Of Envir., Pharm. and Life Sci..2012, 1(4): 4345 .

[41] FAO, Sustainable fisheries and aquaculture for food security and nutrition, Food and Agriculture Organization of the UnitedNations.

http://www.fao.org/documents/card/en/c/63d4de9f-50df49b1-b6d2-b7d0368744ea 2014, Retrieved 20th Oct. 2015.

[42] L. U. Onyia, C. Milam, J. M. Manu and D. S. Allison, Proximate and mineral composition of some freshwater fishes in upper River Benue, Yola, Nigeria. Cont. J. of Food Sci. and Tech., 2010, 4:1-6. 